\title{
The Displaced Naturalist: W. F. Campbell's life of exile in Normandy
}

Le naturaliste déplacé: W. F. Campbell et sa vie d'exil en Normandie

\author{
Lesley Graham
}

\section{revues.org}

Electronic version

URL: http://

etudesecossaises.revues.org/229

ISSN: 1969-6337
Publisher

Ellug / Éditions littéraires et linguistiques de l'université de Grenoble

\section{Printed version}

Date of publication: 30 septembre 2010

Number of pages: 119-128

ISBN: 978-2-84310-173-1

ISSN: $1240-1439$

\section{Electronic reference}

Lesley Graham, «The Displaced Naturalist: W. F. Campbell's life of exile in Normandy », Études

écossaises [Online], 13 | 2010, Online since 30 September 2011, connection on 03 October 2016. URL : http://etudesecossaises.revues.org/229

The text is a facsimile of the print edition.

(c) Études écossaises 


\section{The Displaced Naturalist: W. F. Campbell's life of exile in Normandy}

Few would argue that the concept of home is not intimately linked with the notion of place. People are born into and evolve in attachments that are always based in a place and this natural environment is of quite fundamental importance in the formation of a sense of self. Attitudes to these places are socially constructed, and, to some extent, conditioned by a mental hierarchy associated with the movement of capital from place to place. This paper explores one textual example of what comes about when a person is forced for economic reasons from the area in which he has invested his sense of self and slips down the accepted hierarchy of places from home to away: in this case being displaced from the West Highlands of Scotland to Normandy in France.

The work in question is Life in Normandy, written by Walter Frederick Campbell (1798-1855). Campbell was the Laird of Islay from 1816 to 1848, the island estate having been in the hands of his family, the Campbells of Shawfield, for some 300 years. He was also the reformist MP for Argyll for most of this period (1822-1832 and 1835-1841). Campbell inherited Islay in 1816 and initiated one of the most revolutionary eras in the history of the island through a bold series of reforms, the effects of which are still evident today. ${ }^{1} \mathrm{He}$ created new villages, diversified economic activity, extended the internal and external communications network and imposed agricultural reform. When the price of cereal and cattle fell dramatically at the end of the Napoleonic Wars, confronted with overpopulation, depressed agricultural prices and substantial rent arrears among his tenants, Campbell sought to accelerate the transformation of his estate. He was largely successful in meeting his objective which was to "retain tenants on the estate without outright clearance or large-scale emigration." "2 Consequently, Campbell was generally perceived to be a "humane" and "liberal" proprietor.

1. For a full account of this period see Storrie, pp. 107-34.

2. National Library of Scotland, Lamplighter and Story-teller, p. 23. 
By October 1847, however, Campbell's liabilities were colossal. In December of the same year one of the creditors petitioned for formal bankruptcy and the Islay estate was sequestered. In a "state of hopeless embarrassment" (Walker, p. 822), the destitute laird removed to Avranches in Normandy initially to recover his health. There, he spent the final years of his life as an economic exile, aided by an annuity from his friends. Like Boulogne and Dinan, Avranches was a financial haven for numerous Britons. Since the 1820s, many military families had been living on half-pay in the new period of peace with France and Normandy attracted a growing number of financial casualties who found the cost of living in Great Britain unaffordable. The town probably had what Pemble describes as "the threadbare look associated with bankrupts, officers on half pay, penurious spinsters, and families making do with cut price gentility" (p. 10).

Life in Normandy was published anonymously in 1863, eight years after Walter Frederick Campbell's death. His son, John Francis Campbell (1821-1885), the well-known folklorist, edited the two volumes - a fictionalized account ${ }^{3}$ of a short trip undertaken by the two main characters from Avranches to Granville further along the coast. Hope and Cross, the protagonists of the narrative, are clearly Campbell's alter egos, both characters being passionately interested in nature, fishing and shooting. Indeed, John Francis Campbell confirms in the preface to the third edition that "those who knew the author $[\ldots]$ know that Hope and Cross think his thoughts and narrate many of his adventures" (vol. 1, p. vI). Cross is described as a man having a small independence who found himself the great man of the quiet little town where he lived, poverty in England being wealth in Normandy.

The fictionalization of the account eliminates the dreary description characteristic of so many nineteenth-century travel narratives while it also allows Campbell to present several subjectivities including that of the "West Highland gentleman", that of the Eton-educated older man, and that of the detached narrator, accommodating an interesting heteroglossia that entwines peasant and bourgeois voices from Scotland, France and England.

Given how much nineteenth-century travel writing on France was characterized by an urge to point out just how much better France could

3. Campbell may have been influenced in the literary recycling of life events by his mother Charlotte Campbell Bury (28 January 1775-1 April 1861) after whom he had named Port Charlotte on Islay. Following her second marriage and a period spent as lady-in-waiting in the household of the future Queen Caroline, she became the author of numerous works of light literature, part of a movement that came to be known as the Silver Fork School. Certain of her novels were once extremely popular, the most successful being Diary illustrative of the Times of George IV (1838). 
be if only it were a little more British, it is surprising to discover that the declared intention of these two volumes as set out in the preface is to suggest ways in which the poorest Scots might find new ways of catching and preparing food by adopting French ways.

It was suggested that various ingenious foreign devices and engines for ensnaring, growing and gathering food, and making it eatable, might be described as to benefit the poor at home, whose single dish of potatoes might easily be varied at small cost. It was argued that a good cheap dinner would tempt a poor man from bad dear drink abroad, and that a poor Scotchman's wife might be taught to do that which poor wives do elsewhere. (Vol. 1, p. v)

This paternalistic effort to incite Highlanders to improve their way of life by learning from French example has to be understood in the context of the extreme poverty and devastating distress brought about on Islay by the potato blight just two years before Campbell's exile. The declaration echoes several of the very problems at the origin of Campbell's exiled state: the poverty of the people of Islay who could no longer pay him their rent; their dependence on the potato; and their penchant for alcohol. When the potato blight struck in 1846, it was reported that over 5,000 inhabitants of Islay were suffering "pressing wants and impending starvation" (Storrie, p. 133). At the end of October 1846 Campbell sought public assistance for the population on his estate claiming that ninety-five percent of the seventeen thousand individuals under his protection were in "great distress" (Walker, p. 821).

Campbell obliquely suggests that the people of Islay might have found the material resources to overcome this crisis but had neither knowledge nor skill enough to do so. His many propositions for improvements that might be adapted in Scotland range from decks on fishing boats (vol. 2, p. 241), a pulley system for baskets covering food (vol. 1, p. 123), the four de campagne (vol. 1, p. 126), an organized market for fish (vol. 1, pp. 218-9), and cooking techniques that might render seabirds edible. The character Hope claims:

[...] a Frenchman will live in luxury where our people would starve, merely from knowing how to make the most of what falls in his way. I confess I wish that our peasant women in Scotland knew something more of cookery than merely boiling a potato. Certainly our friend the Marquis errs quite as much in the one way as our Highland wives do in the other; still, if he can show us how to convert marrots into good food, the lesson is worth learning, for what myriads of them have I seen on the coasts of Scotland which might benefit our poor, instead of merely destroying the herring fry. So let us go and see how he gets on, and try to teach his method to some of the people at home. (Vol. 1, p. 57) 
Campbell's approach is an interesting variation on the customary traveller's prospective transformative project for new lands visited. Instead of considering that the host country is available for improvement, Campbell explicitly directs his suggestions northwards to home, and backwards in time to a catastrophic period for him personally. So that, far from looking forward to the glorious vision of improvement in the country in which he currently resides, the usual trope in 19th C travel narratives (Pratt, p. 61), his suggestions for improvement are sad reminders of lost opportunities at home, his own financial errors and catastrophic natural events.

In an effort to make his exile and this account of it meaningful, Campbell's principal strategy is that of exchange: the exchange of knowledge and experience between Highland Scotland and Normandy with himself as the textual intermediary. However, the exchange is ineffective since few of the potential beneficiaries will ever read his work. It is, rather, an assertion of Campbell's identity as a dignified subject, an expert in both Highland and Norman localities and a useful, if displaced, agent of enrichment through exchange. The account is shadowed by a rumination on the torment occasioned by the motivation for the author's presence in Normandy-financial ruin. I would like to suggest, then, that given Walter Frederick Campbell's personal circumstances, more than merely being a self-help book for distressed islanders, the text can been approached as a reflection on the notion of home and the catharsis of exile, discursively concentrating the author's strategies for coping with an acute sense of both social and cultural dislocation.

As an amateur naturalist, Campbell's observations certainly centre more often than is usual in this type of work on questions of home in the natural environment and more precisely expulsion from home and return to that place of origin: thus as well as learning about flight patterns and plumage and reproduction, we find conjecture about the homing instinct of the salmon, descriptions of digging kingfishers out of their nests in river banks, ruminations on the migration patterns of various birds and comparison of their arrival dates in Scotland and in France, as well as observations on the excavation of the holes inhabited by giant squid and the process of hauling them out of their hiding place with hooks.

Campbell's precarious financial situation and his displacement also resonate in several long passages on natural dangers. The first of these episodes takes place when Hope and Cross are caught out by the tide and find a temporary, uncomfortable home on a rocky island. Fear mounts and a feeling of powerlessness overtakes them until they are saved by a heroic effort from one of the fisher girls who puts her own life in danger to do so. "I went through all the stages, from the cold perspiration of good honest fear to the quiet resignation of despair" admits Hope (vol. 2, 
p. 89). An earlier evocation of the sensation of being pulled under involves stories of a kraken dragging whole boats under the sea and an encounter with the minaur or giant squid:

"How disgustingly ugly and revolting it is!" said Hope [...] "How would you like, Cross, to have that brute clinging round you, sucking you in with all those leech-looking mouths?" (Vol. 1, p. 297)

Fog and walking in circles are the dangers evoked in another pivotal episode that can be interpreted as allegory.

I felt that death was inevitable, and mine was the calmness of resignation to a certain fate which I could not avert. Fear is most painful while there remains any uncertainty; when doubt ceases, fear in a great measure ceases also, and resignation takes its place. (Vol. 2, p. 89)

A similar passage juxtaposes parallel incidents, one that took place on the sinking sands around the Mont Saint Michel and another on a strand in the West Highlands. "I felt myself slowly going down" (p. 100) writes Campbell, and even as he describes the terrible feeling experienced in Normandy, he harks back to Scotland, its bogs, trembling eyes and well-heads (p. 101). All of these brushes with death - the rising tide; getting lost in thick fog; sea monsters; and sinking sands - are irresistible reminders of the helplessness Campbell must have experienced as he struggled to keep his head above water financially, slowly losing Islay and his livelihood.

The sensation to me was as if a slight crust had broken under my feet, through which they sank, and then something seemed to suck or drag me down, leaving me not the slightest power to assist myself. (p. 101)

One of the ways that exiles play out the tension created by their displacement is by doing boundary work, that is consolidating the definition of what is "us" and what is "them". Avranches in the mid-nineteenth century surely qualifies as what Pratt in the colonial context has theorized as a contact zone, that is: a social space "where disparate cultures meet, clash, and grapple with each other, often in highly asymmetrical relations of domination and subordination" (Pratt, p. 4). From the very outset of this narrative, Campbell goes about establishing his difference by creating the impression that Normandy is in many ways a hostile environment. The action in Normandy takes place against the background of rumblings from the 1848 Revolution in Paris with one insurgent taking refuge in the inn in which Hope and Cross are lodging in Granville, lending a whiff of ambient menace to the exiles' presence in an unpredictably turbulent foreign land. 
In the very first chapter, Hope and Cross are harassed by a group of men from Granville who hurl stones at them and chant "Sur la France l'Anglais / ne régnera jamais" (vol. 1, p. 51). The local men in turn are described over the space of thirty-two pages as blackguards, scoundrels, rascals, persecutors, confounded French frogs, vermin, scum of the earth, scamps and tormentors (vol. 1, pp. 51, 53, 58, 59, 82, 83). The altercation comes to a head when a band of around fifty men marches down the road with pitchforks and scythes only to be settled by Cross asserting his economic power by proposing to palm them off with "a few fish hooks and a franc or two" (vol. 1, p. 82).

The jostling to assert social and cultural domination is played out throughout the travel narrative with multiple subtle examples of discourses that promote bourgeois authority and devalue French subsistence ways of life (Pratt, p. 10). In general, the Norman peasants are portrayed as being childlike and social order is reassuringly respected by the young fisher girls:

in spite of "liberté, égalité", they were shy and respectful, and as soon as they had finished eating, they rose, curtseyed, and left the room. (p. 245)

The maintenance of these class barriers is all the more important in France, where social status less easily perceptible than in Great Britain. The Marquis, for example, sometimes dresses like a peasant and is portrayed as being somewhat limited intellectually and abnormally preoccupied by the preparation and consumption of food. Language is also used to reinforce stereotypes and anchor boundaries. The Marquis' French is transposed into the sort of deficient English that consolidates his portrayal as a somewhat ridiculous character.

Several aspects of Campbell's text reflect interactions based on domination and subordination and serve to remind the reader that although he may be exiled in terms of nation he maintains his social class. Despite reduced circumstances, Campbell seeks to convey his undisputable membership of the upper classes ${ }^{4}$ and the narrative dramatizes an unquestioned domination exerted over the peasant population of Normandy. However, he also clearly considers himself a benevolent benefactor and this quality is acted out in his account during an episode in which Cross and Hope use their financial resources to reward the young fisher-girl who had saved them from the rising tide, thereby simultaneously asserting their authority and their economic superiority.

4. Indeed, he had even greater aspirations. The Campbell papers in the National Library of Scotland include a draft letter from W. F. Campbell to the Duke of Argyll concerning his desire for a peerage. 
The following passage relating Hope's shock at coming upon a rather slovenly house in the Norman countryside serves to maintain several boundaries; that between social classes, that between Celts and everyone else, and that between France and Great Britain.

"Talk of French civilisation", said Hope; "I will be hanged if this does not beat Celtic indolence. You may see the same sort of carelessness among the lowest orders of Welsh, Irish, and Scottish Highlanders, but not among the better class. The proprietor of this place, you told me, is rich, is in the employment of the government, and considers himself enough of a gentleman to call me out, if I told him what I think of his dirt and ignorance." (Vol. 1, p. 122)

The passage also clearly illustrates the value of fictionalizing the account and including characters with different points of view. Only Hope, the old Etonian, can make such a remark since the character Cross represents West Highland wisdom and tolerance. Cross's response immediately re-establishes the objective voice of reason appropriate to a conspicuously impartial observer: "C'est la mode du pays", answered Cross; "and as we are not their schoolmasters, we must take them as we find them" (vol. 1, p. 122). "It is always more agreeable to praise than to censure" he adds.

Cross's innocent stance is typical of many naturalists writing about abroad. Indeed, the "natural" authority exerted by Campbell's protagonists over the local population is reinforced by their status as amateur naturalists. Going beyond the obvious contrast between the local people who live off the land and the exiles taking a dilettante scientific interest in it, Pratt has further examined the relationship between naturalists and locals in the colonial context and identified "an ideological drama essential to the authority of the naturalist, that of validating his way of knowing over others" (p. 55) often involving clashes between peasant knowledge and science. She further claims that the conspicuously innocent stance invariably taken by the naturalist reflects an assumed guilt of conquest and a great longing for a way of taking possession without subjugation and violence (p. 57).

The undeniable otherness of Normandy is typically illustrated by Campbell through descriptions of unfamiliar eating habits and exotic foodstuffs. The two volumes of Life in Normandy are peppered with these, notably with enumerations of the various courses in the gargantuan meals prepared by the French Marquis. The detailed descriptions serve to establish the fact that Normandy is decidedly not home but also suggest that the most savoury elements from it might be integratedindeed ingurgitated - into Campbell's new identity as an exile. These 
possibilities, however, are counterbalanced by descriptions of unequivocally alien foodstuffs such as limpets (apparently eaten in Normandy while periwinkles are not) (vol. 1, p. 191), snails and even slugs (vol. 2, pp. 16-20), and guillemots (vol. 2, p. 47), as well as bacon that because of the gabelle has to be cured by burying it in the earth for six months in a modest amount of salt. This last practice provides the author with the opportunity to voice his rejection of this repugnant element in the Norman diet while at the same time affirming the superior discernment of his compatriots by declaring that it gives him "what the Scotch call a regular scunner" (vol. 2, p. 134).

The preoccupation with a possibly useful "otherness" available for appropriation is mirrored by a similar preoccupation with "sameness". For the exiled subject sameness provides stability and comfort. It is a discursive coping strategy. In this way, numerous parallels are drawn between Normandy and Scotland or more generally Great Britain: between the horses, the fields, the roads, the housewives and their collections of linen, girdles, drinking habits, and penny weddings. "The habits and superstitions which I observe resemble much more those of Scottish Highlanders than of the English" concludes Campbell (vol. 2, p. 304). Levi Strauss asks: "What does travel ultimately produce if it is not, by a sort of reversal, an 'exploration of the deserted places of my memory', the return to nearby exoticism by way of a detour through distant places, and the 'discovery' of relics and legends" (quoted by de Certeau, p. 107). Accordingly, Norman otherness and sameness produces in Campbell a heightened awareness of the abandoned myths and legends of home and, at the same time, underlines the sameness of Highland Scotland and Normandy: original home and adopted home. A single example will suffice: that of magpies as birds of augury. Hope remarks that in England it is considered fortunate to see an even number of magpies and unfortunate to see an odd number.

One is sorrow, two is mirth,

Three's a wedding, four's a birth.

Ay, that is the English edition, and put together for the sake of the rhyme; but our Highland belief agrees with the Norman. We think that the uneven numbers are fortunate, and the even unfortunate. In the Highlands the lines are-

One is joy, two is grief,

Three a wedding, four a death. (Vol. 2, p. 221)

Another of the discursive techniques used both to assert the traveller's authority and expertise, and to establish correspondences between 
home and here, is that of glossing unfamiliar terms. Glossing provides a way of re-establishing some semblance of order on the natural world since one of the sources of the alienation associated with exile is that the signifier has become severed from the signified, that words no longer stand for things in an unquestionable way. The mission for the expatriate, and to an even greater extent for the exiled naturalist, is thus to supply the "correct words" for foreign terms. Lexical correspondences must be found and pointed out, as in the following explanation provided by the Marquis:

Bouquets are what you call prawns; chevrettes are shrimps; in Paris and in most parts of France, prawns are called salicoques, and shrimps crevettes, but here they bear the names of bouquets and chevrettes. (vol. 1, p. 141)

Glosses are provided by Campbell for many of the terms associated with the fauna and flora of Normandy although the process can be rather confusing given that the correct word may simply be considered the English word or more rarely the scientific word, but sometimes it may be the Scots word for a Norman term. Thus, in dialogue, familiar words are substituted for strange terms and the otherness is controlled, and sometimes even rendered homely with the substitution of that Scots word. On at least one occasion, Campbell is pleased to note that the Norman word is in fact the same as the Scots word:

[...] little Matilde held one of the poles with the iron hooks, which she called by the same name as the salmon-fisher in Scotland gives to his landinghook - namely, a clip. The one Matilde carried was exactly of the same form as those used by the northern salmon-fisher, but was six times as strong, looking more like a short boat-hook, without the spike, than a clip. But a clip it was called. (Vol. 1, p. 285)

The narrative also unselfconsciously contains Scots words such as burn, caller, blether, and burthen that are not glossed, suggesting that both W. F. an J. F. Campbell used these terms naturally and expected their readers to understand them too. ${ }^{5}$

Alas, Campbell was never able to take those words back to their natural habitat. There was to be no Scottish homecoming at the end of his life for he died and is buried in Avranches cemetery where the inscription on his gravestone reads: "Where your treasure is there will your heart be also." It is clear that despite a sincere effort to live a useful life in France, Walter Frederick Campbell's sense of self was never completely invested

5. Occasionally, however, Scots terms in dialogue are glossed, ostensibly for the benefit of the French Marquis: this is the case for the term "leister and blaze" for example (vol. 2, p. 51). 
in his place of exile and that he never entirely came to terms with his displacement. So that even as he wrote about life in Normandy, he was constantly and obsessively reworking thoughts of his home, Islay, and of the circumstances of his expulsion from it. The clues in the text reveal a man as intrigued by similarities between Highland Scotland and Normandy as by differences between the two places and a benevolent individual intent on learning from this experience and transferring the knowledge acquired to those who might benefit from it at home. At the same time, they betray a mind endlessly ruminating on the meaning of home in the natural world, the helplessness that accompanies going under be it financially or literally, the dislocation of exile and the need to maintain and cultivate social barriers as well as cultural differences.

\section{Bibliography}

[CAmpbell Walter Frederick], Life in Normandy Life in Normandy; sketches of French fishing, farming, cooking, natural history, and politics, drawn from nature, Edinburgh, Edmonston \& Douglas, 1863.

J. F. Campbell Collection, Special Collections, National Library of Scotland, MS. ADV $-50-59$.

Certeau Michel de, The Practice of Everyday Life, Berkeley, University of California Press, 1988.

National Library of Scotland, Lamplighter and Story-teller: Fohn Francis Campbell of Islay, 1821-1885 [exhibition catalogue], Edinburgh, 1985.

Storrie Margaret C., Islay: biography of an Island, Port Ellen, The Oa Press, 1981.

Pemble John, The Mediterranean Passion: Victorians and Edwardians in the South, Oxford, Oxford University Press, 1988.

PratT Mary Louise, Imperial Eyes: Travel Writing and Transculturation, London, Routledge, 1992.

Walker Stephen P., "Agents Of Dispossession And Acculturation. Edinburgh Accountants And The Highland Clearances", Critical Perspectives on Accounting, vol. 14, no. 8, November 2003, pp. 813-53. 